\title{
How to Construct a Sympotic Space with Words
}

\author{
Jenny Strauss Clay
}

The Greek symposium, where most archaic Greek monodic poetry was performed, took place in a space defined by couches arranged along the walls of a special room on which the company reclined; the krater in which wine and water were mixed for the communal drinking occupied the center of the andron. ${ }^{1}$ As vase-paintings show, the walls were often decorated with various objects that contributed to the definition of the sympotic group: armor, baskets, and musical instruments. I intend to examine Alcaeus fr. 140 V., Xenophanes fr. 1 W., and Theognidea $467-496$ to show how all three compositions construct the setting of the symposium verbally. Both Alcaeus and Xenophanes describe the andron by, in the first case, visualizing the space from the ceiling to the floor, while in Xenophanes, inversely, the eye moves from the floor to the central space occupied by the krater before ascending, metaphorically, to the gods above. Using yet another strategy, Theognis' verses shape the sympotic space through a series of deictic pronouns that progress through the exclusion and inclusion of participants and appropriate modes of behavior. The sequence culminates in the creation of a community that shares in the harmony and euphrosyne that are the hallmarks of the ideal symposium.

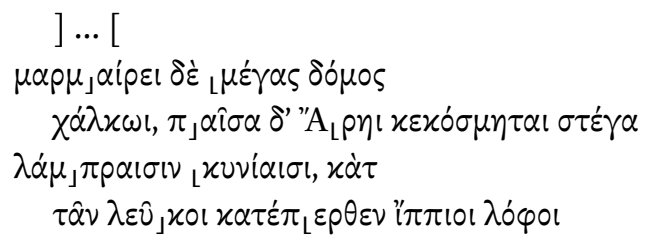

1 For the symbolism of the central position of the krater, see Lissarrague (1990) 19-46. This paper grew out of a serendipitous coincidence: I was completing my book on space and vision in the Iliad (Homer's Trojan Theater, Cambridge 2011), and happened also to be team-teaching a course on the Greek symposium with my colleague at Virginia, Malcolm Bell III, from which I greatly benefited. The Iliad project allowed me to see things in a way I hadn't before with a far greater sensitivity to the spatial dimension of early Greek poetry including its performance setting. This paper was submitted in 2010; I have not been able to revise it drastically, but am happy to acknowledge the help of Vanessa Cazzato who directed my attention to Faraone (2008) and Hobden (2013).

(C) JENNY STRAUSS CLAY, 2016 | DOI: 10.1163/9789004314849_009

This is an open access chapter distributed under the terms of the Creative Commons Attribution-

Noncommercial 3.o Unported (CC-BY-NC 3.0) License. 


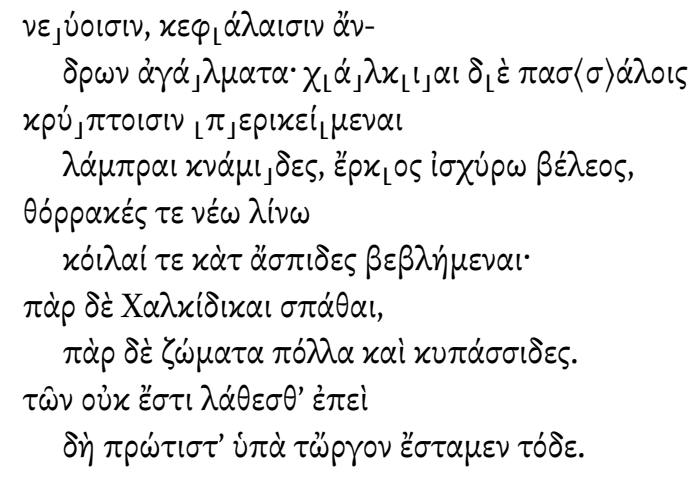

The great house sparkles

with bronze, the whole ceiling is adorned for Ares

with shining helmets, from which horse-hair crests

nod down, ornaments for

the heads of men; bronze shining greaves

hanging about hide the pegs,

a barrier against mighty missiles,

corselets of new linen

and hollow shields thrown down;

beside them broad swords from Chalcis, and beside them many belts and tunics.

It is impossible to forget these things, ever since first we undertook this task.

Most discussions of Alcaeus fr. $140 \mathrm{~V}$. focus on the description of the armor catalogued in the poem. Is it contemporary or antique? 'Eccentric and oldfashioned' claimed Page, but nevertheless 'Alcaeus is describing the equipment of his comrades-in-arms, not that of legendary heroes'.2 Snodgrass, however, believes that 'apart from the linen corselets ... and the belts which go naturally with them, this is standard hoplite equipment.'3 If the items are indeed those in use in Alcaeus' own time, do they belong to typical local armor or are they possibly armor captured from enemies? In other words, are they spoils or not? ${ }^{4}$

2 Page (1955) 211-212.

3 Snodgrass (1967) 65.

4 Spoils: Bonanno (1990) 125-146; Cirio (1995): spoils, but expected to be re-used. Perrotta, Gentili, and Cantenacci (2007) 176 argue that the armor is new and therefore cannot be votives offered at a temple. 
The second focus of discussion has been on the mega domos: is it a temple, a heroon, or a sympotic andron $?^{5}$ On the basis of the dative "Appı at line 2, Bonnano, followed by Marzullo, has argued that the megas domos must be identified as a temple of Ares and that the various pieces of armor should be considered votives. ${ }^{6}$ And, indeed, armor constitutes a common form of votive dedication in early sanctuaries - one need only think of Olympia and Delphi. But the notion of a temple to Ares on Lesbos is extremely unlikely. In fact, we have evidence for only one temple dedicated to Ares in Greece, and that is the notorious and very late 'wandering temple' in the Athenian agorawhich originally may not have been a temple to Ares at all. ${ }^{\text {"Apn }}$ เ in line 2 may simply be the common metonymy for 'war'. ' Cirio argues for a heroon of the Mycenaean tholos type, where indeed we find votive deposits, but the island of Lesbos has not produced such tombs. Citing Athenaeus 14.626 f.-627b, who calls the poem's locale an oikia, Colesanti more persuasively argues for the performance setting of an andron, ${ }^{9}$ but we do well to keep in mind that sympotic spaces are often to be found in sanctuaries, whether connected to a heroon or a temple dedicated to a god. ${ }^{10}$ Some of our earliest evidence for sympotic architecture comes from sanctuaries; here I mention the recently excavated series of dining rooms, among the earliest known, in the archaic sanctuary of Apollo on the tiny island of Despotiko near Antiparos. ${ }^{11}$ Indeed, dining and sympotic activity have been demonstrated at many such sites; as a result any simple distinction between private and public banquets has rightly been thrown into question by, among others, Schmitt-Pantel. ${ }^{12}$

Insofar as so much of Greek lyric poetry was performed in a sympotic context, it thus makes sense to situate Alcaeus' poem in such a setting, but

Temple of Ares: Bonanno (1990) 125-146; Marzullo (2009) 12; arsenal or storeroom: Treu (1952) 158; heroon: Cirio (1995), (2001) with reference to Alcaeus fr. 383 v.; andron: Page (1955) 222-223; Rösler (1980) 148-158; Perrotta, Gentili, and Catenacci (2007) 176.

$6 \quad$ Marzullo (2009); Bonanno (1990).

7 Cf. Der neue Pauly I 1049-1050, s.v. Ares; and Spawforth (2006) 136-137.

8 Some scholars have suspected the reading "Apทl; see Voigt's apparatus ad loc.

9 Colesanti (1995), who, however, denies the disposition of the arms from ceiling to floor: 'Una tale disposizione è però strana e niente affatto probablile', and he opts for 'una disposizione mista' (390). Cf. Page (1955) 222: 'The poem was presumably sung by Alcaeus to his comrades at the dining table', and he cites the andron of Croesus, which was similarly furnished with weapons and other armaments (Herodotus 1.34.3) as well as the megaron of Odysseus' palace (Od. 16.284). See also Colesanti (1995) 393 n. 1.

10 See, for instance, Bookides (1990); Goldstein (1978); Will (1976); Roux (1973).

11 See Kourayos (2005) 105-133.

12 Schmitt-Pantel (1990) and (1992). 
my interest here is rather in the space constructed within the poem. We begin with the roof adorned with shining helmets; our gaze then follows the horsehair crests 'nodding down' from above (lines 4-5). As our gaze proceeds downward, we encounter greaves hanging from pegs, which one assumes are affixed to the walls, as well as corselets of new linen. Now we arrive at the ground, where shields are thrown down on the floor; beside them, presumably also on the floor, are broad swords from Chalcis and tunics or perhaps cloaks. ${ }^{13}$ Armor is often depicted as adorning the walls of sympotic scenes on vase painting. ${ }^{14}$ But the objects on the ground may suggest a more immediate use, i.e. ready for action? Finally, in light of the spatio-visual ordering of the catalogued items, the exhortation not to 'forget these things' may involve more than merely remembering their symbolic value to inspire courage, but may offer a mnemonic device for recalling the scene and its setting each time the poem is sung, creating for the hetairia a shared communal vision.

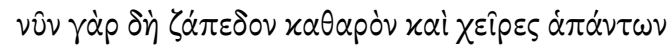

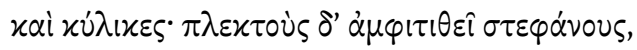

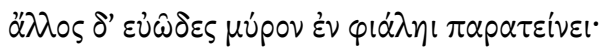

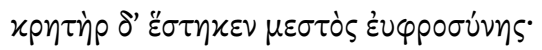

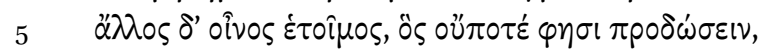

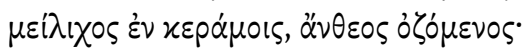

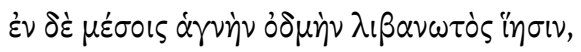

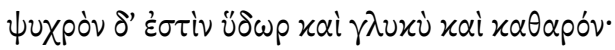

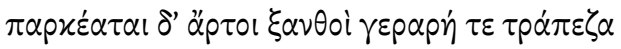

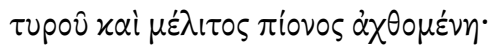

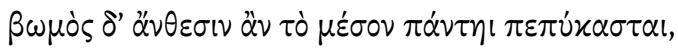
$\mu о \lambda \pi \dot{\eta} \delta^{\prime} \alpha \mu \varphi i \varsigma$ है $\chi \varepsilon l \delta \omega^{\prime} \mu \alpha \tau \alpha$ xai $\theta \alpha \lambda i \eta$.

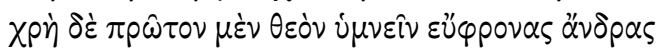

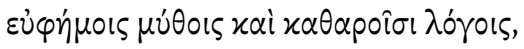

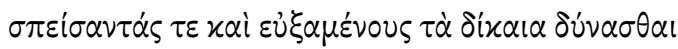

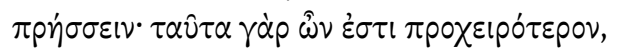

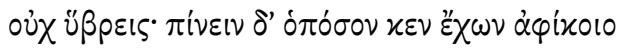

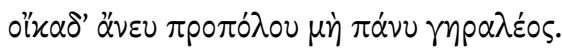

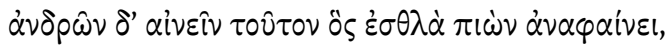

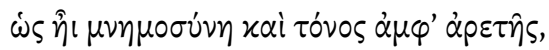

13 Cf. Bonanno (1990) 137.

14 See the plates in Colesanti (1995). 


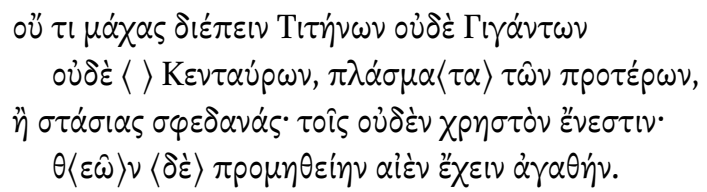

For now indeed the floor is clean and everyone's hands

And the cups; one dons braided garlands, another passes fragrant myrrh in a bowl;

the krater filled with good cheer has been set up;

another wine is at the ready, which claims it never will prove false,

mellow in the cups, and smelling of flowers;

and in the middle incense sends forth a pure fragrance,

cool is the water and sweet and pure;

blonde loaves of bread are set out too and a splendid table weighed down with cheese and thick honey;

an altar in the center is completely covered with flowers, and song and festivity pervade the house.

Men of good cheer must first hymn the god with reverent words and pure speeches, while pouring libations and praying to be able to do what is just, for these things are closer at hand, rather than acts of hybris; and to drink only so much to make it home without a servant (unless you're very old); praise the man who when drinking reveals excellent things, so that there is recollection and striving for excellence; nor at all recounting the battles of the Titans nor of the Giants nor of the centaurs, fabrications of men of old, or of violent factions - in which there is nothing of usebut always to have a good regard for the gods.

Xenophanes' fr. 1 w. likewise describes a sympotic space, this one perhaps more symbolic and ideal than real. But here the order is inverted: Xenophanes begins from the floor, freshly swept. He then enumerates various accoutrements of the participants, their clean hands and cups; then movement enters the scene with their sundry preparations: putting on of garlands, passing of perfumes. We proceed to the middle space, occupied by the krater, incense, and pure water. Nearby are tables laden with bread, cheese, and honey. The altar at the center is covered with flowers; finally music and thalia, the sense of well-being and

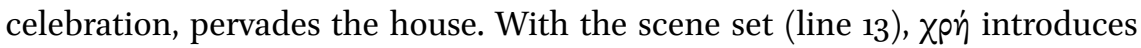
the activities appropriate in this setting. The emphasis on purity/cleanliness 
and the altar, mentioned in line 11, prepares for them: hymns to the gods, libations and prayers, 'for these things are closer to hand' (line 16) as opposed to immoderation and excessive drinking. Song and prayer introduce the subject

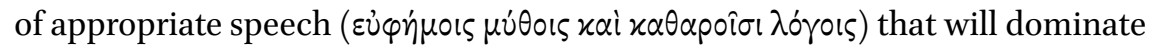
the rest of the poem.

As we know from several sources, ${ }^{15}$ the singing of the sympotic paean along with a series of libations preceded the orderly competition from right to left, epi dexia, among the symposiasts, whether with poetry or speeches. In Xenophanes' symposium, the prize goes to the man who brings noble things to light, deeds that 'inspire commemoration and competition in virtue' ( $\dot{\omega} \varsigma \hat{\eta} \iota \mu \nu \eta \mu \mathrm{o}$

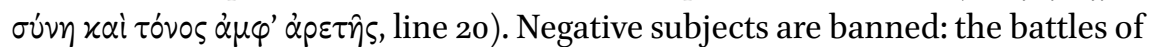
the Titans and Giants are here viewed not as paradigms of the triumph of the Olympian order against chaotic forces, but rather as negative examples to be excluded from the party. Likewise Centaurs, who frequently function as warning exemplars of barbaric behavior at a symposium, ${ }^{16}$ are similarly barred, as are all kinds of violent strife, especially civic strife: they have nothing useful to teach. The important thing is to have a positive attitude, $\pi \rho \circ \mu \eta \theta \varepsilon i \eta \eta \dot{\alpha} \gamma \alpha \theta \dot{\eta} v$, toward the gods.

Now, my paraphrase has not gone into some of the controversies surrounding the final lines of the poem, nor whether Xenophanes is offering a new theology. Here again I am more interested in the way Xenophanes constructs the symposium both spatially and temporally. The preparations (lines 1-12) are described as a visual progression (I recognize also the importance of smells in the catalogue), moving from the floor to the krater, the tables, the altar, and finally the whole house awash with music and conviviality. The second 12 lines (lines 13-24) balance the first, but focus on sound and speech and the appropriate temporal sequence of sympotic activities: hymns, libations, prayers, and competitive speeches. I suggest that the two sequences come together in the last line of the poem with the gods, present in the central bomos and in the culminating vertical trajectory of the poem, from floor to heaven itself, the abode of divinity. In his commentary, Lesher aptly speaks of the poem's 'progressive elevation of sentiment, aptly symbolized by the upward progression from the floor (l. 1) to table (l. g) to house (l. 12) to human excellence (l. 20) to respect

15 E.g. Xen. Symp. 2.1; Xen. Cyrop. 4.1.6; Plat. Symp. 176 a.

16 As early as the Odyssey; see Od. 21.295-304. Centaurs and Lapiths are common motifs in sympotic vases; see Lissarrague (1990) 30-31 for an example. The exclusion of even a negative example from Xenophanes' symposium reveals that he is describing not just acceptable behavior, but something more radical and new. 
for the gods (l. 24)'. ${ }^{17}$ However, Lesher overlooks the sympotic character of the poem, comparing the scene to 'the wholesome family dinner' Plato describes at Republic 372b. Yet Xenophanes' scenario has nothing rustic about it, and the fare is typical of sympotic snacks or tragemata. ${ }^{18}$

Having now explored the sympotic space from the top down with Alcaeus, and from the bottom up with Xenophanes, we will join Theognis (467-496) or whoever the author of these verses might be (perhaps Euenus) ${ }^{19}$ - in a tour around the andron.

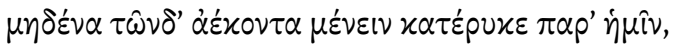

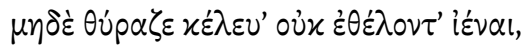

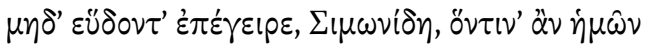

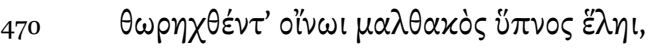

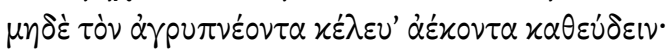

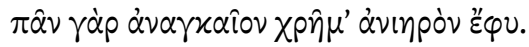

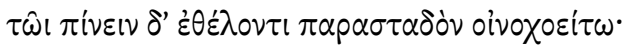

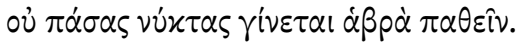

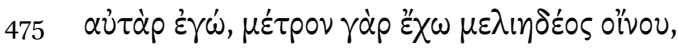

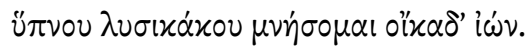

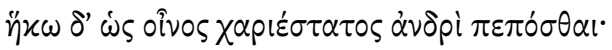

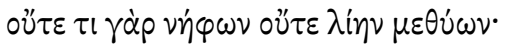

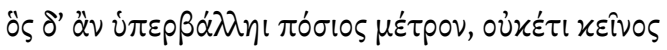

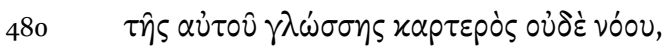

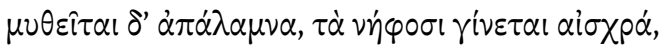

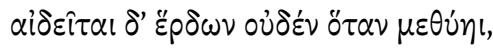

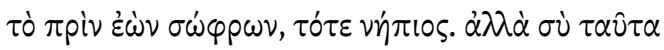

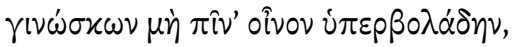

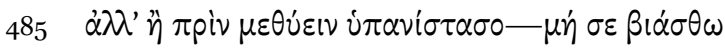

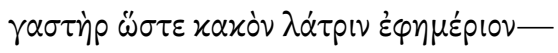

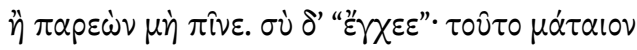

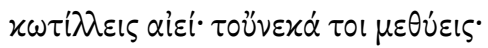

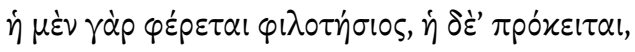

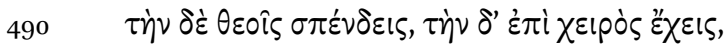

17 Lesher (1992) 54 .

18 Cf. Marcovich (1978) 5 .

19 The elegy has been attributed to Euenus on the grounds that Aristotle cites Euenus as the source for line 472 (cf. Carrière [1948] 110). But the line is surely proverbial and may be drawn from the Theognidea or from a common source. It is unnecessary to identify Simonides with the poet of Ceos. 


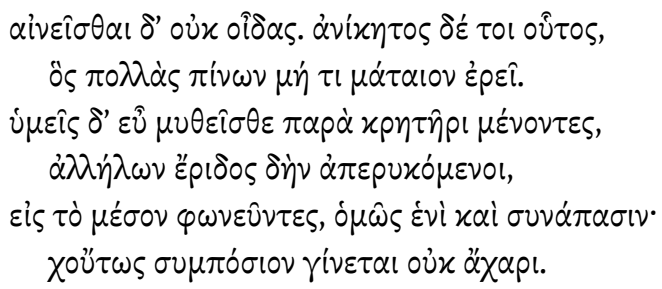

Do not force anyone of those here to remain among us against his will, nor order anyone to leave if he doesn't wish to;

nor, Simonides, awaken the one who is sleeping, whoever of our company, soft sleep overcomes, drunk on wine, nor order the wakeful to go to sleep against his will; everything done under compulsion is naturally irritating. Let him pour standing by for the one who wants to drink; it's not every night that one can luxuriate.

But I, for I have a due measure of honeyed wine, I'll bethink myself of sleep that frees from pain going home. ${ }^{20}$

But I have arrived at the point when wine is most pleasing for a man to imbibe; for I am neither too sober or too drunk;

but whoever should exceed the due measure of drink, no longer is that one in charge of his own tongue or mind, and he blathers useless stuff which is embarrassing to the sober, nor does he feel shame no matter what he does whenever he's drunk, the same man who was sensible, then acts the fool. But you, knowing these things don't drink wine to excess, but before getting drunk, get up from under-so that your stomach doesn't plague you like a bad day-laborer-

20 Gerber (1999) 243 translates $475^{-476}$ as follows: 'But I'll go home-I've had my limit of honey-sweet wine - and I'll take thought for sleep that brings release from ills.' This is at odds with the following line, which Gerber translates: 'I've reached a stage where the consumption of wine is most pleasant for a man.' I do not believe that the speaker is threatening to go home or that he has reached his limit. Cf. Faraone (2008) 87, who gives Gerber's translation, and Hobden (2013) 59, who translates: 'But I, since I hold the measure of honey-sweet wine, shall give heed to evil-ending sleep and go home'. Rather, the speaker claims emphatically $\left(\dot{\varepsilon} \gamma \omega^{\prime}\right)$ that he has at hand a due measure of wine and will think about going home and sleeping in due time. At present he has reached that most pleasant state described in the following line. 
Or stay around without drinking. But you always keep up your empty

babbling: 'fill 'er up'; that's why you get drunk;

The first round is for a friendship toast; another appears,

the next you pour to the gods; the next you have in hand;

you don't know how to say no. Unbeatable is the man who,

while drinking lots, does not speak nonsense.

But you all speak decorously as you stay near the krater,

keeping quarrels at a distance from each other, speaking for the common good, both for one and all.

And thus our symposium will be not without its charm.

While West and others view lines $467-496$ as one poem, and hence one of the longest sustained compositions in the collection, Faraone has argued that we have here what were originally three independent ten-line stanzas that nevertheless form a chain and respond to one another. ${ }^{21}$ Faraone's analysis of the poem's structure is, however, problematic. First, he must consider his first stanzaic division at line 476 , whereas the previous couplet ending with 474 (oi

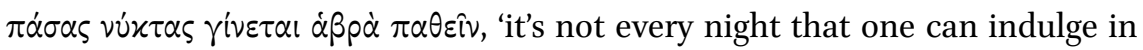

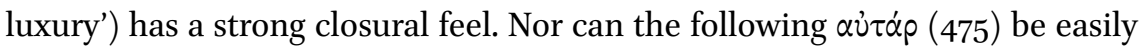
separated from " $\chi^{\prime} \omega \omega \delta^{\prime}$ (477), which continues to explicate the 'due measure' ( $\mu \dot{\varepsilon} \tau$ ipov, 477) expounded by the $\dot{\varepsilon} \gamma \dot{\omega}$. Finally, as Hobden has already pointed out, Faraone is obliged to divide line 487 and use special pleading to argue 'that a scribe placing the poems together altered their last and first lines to fit. ${ }^{22}$

My understanding of the poem is not only predicated on its unity, but also involves careful attention to its deployment of the pronouns and deictics and on our recognition of the configuration of a typical andron. It seems to me most effective to trace the progress of the composition from beginning to end and to understand how the poem itself functions to construct the sympotic group both spatially and ethically.

The opening establishes the presence of various participants $(\tau \hat{\omega} v \delta$ ', 'these here') in the here and now of the enunciation. Moreover, it creates a shared group identity ( $\dot{\eta} \mu \hat{\imath} v, \dot{\eta} \mu \hat{\omega} v$, 'we') from which no one of those present is excluded ( $\mu \eta \delta \dot{\varepsilon} v \alpha \tau \hat{\omega} v \delta^{\prime}$, 'no one of these here'). Finally, $\mu \dot{\varepsilon} v \varepsilon \varepsilon v$ indicates a space which each of the members shares. However, that membership is a matter of choice: to depart from this deictic center ( $\theta \dot{\rho} \rho \alpha \zeta \varepsilon$... ićval, 467) should be a matter not

\footnotetext{
21 Faraone (2008) 86-92.

22 Hobden (2013) 6o, n. 76. Nevertheless, Hobden later (61) speaks of 'the third segment or poem'.
} 
of compulsion, but of personal preference, and it does not lead to expulsion from the community. Similar is the couplet that follows: the one who is asleep,

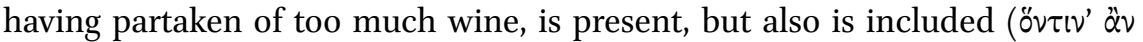
$\dot{\eta} \mu \hat{\omega} v$, 'whoever of us'); while 'this one' ( $\tau \dot{o} v)$ is not to be compelled to sleep (469470). So far, an inclusive membership, but this unity will soon be splintered. The ultimate function of the poem will be to restore that initial unity. At this point, an addressee emerges: Simonides, to whom, as we now recognize, the previous commands have been addressed. He too belongs to the group, but it appears that the speaker is in a position to give him advice. ${ }^{23} \mathrm{~A}$ proverb provides a

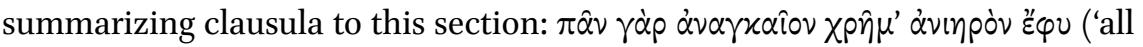
compulsion is a source of irritation,' 472).

The second person address is now abandoned as the speaker continues: 'let him pour the wine standing beside the one who wishes to drink', which continues the idea of freedom of choice. In sympotic depictions the winepourer is often a youth, a kind of apprentice-symposiast, who stands rather than reclines, and is not yet fully a member of the group-which may explain the third person imperative. Another generalizing statement complements the earlier gnome concerning the absence of compulsion; it too characterizes the sympotic environment, $\dot{\alpha} \beta p \dot{\alpha} \pi \alpha \theta \varepsilon i v$, the atmosphere of ease and luxury so typical of sympotic activity (474).

The emphatic entrance on the scene of the speaker raises the question of his relation to Simonides. I am inclined to think that the $\dot{\varepsilon} \gamma \omega \dot{\omega}$ is playing the role of symposiarch, while Simonides may be the host at whose house the party takes place-but this is pure speculation. $\gamma^{\prime} \boldsymbol{\omega}$ then outlines an ethic of moderation; he will drink in moderation, neither falling asleep at the party, nor staying up all night, but go home neither too drunk nor too sober (475-478). Against ego's model behavior stands Mr. Keinos, the one who is distant, not just physically but ethically; he provides a paradigm for the present company to avoid. Unlike Mr. Ego, 'That One' oversteps the $\mu$ ŕtpov of drink, loses control of tongue and mind, and babbles pointlessly so as to shock the sober; then losing all sense of shame and whatever good sense he previously possessed,

23 Hobden (2013) 59 sees a rivalry between the speaker and Simonides, whom she calls 'the leader of the symposium.' She follows Faraone in viewing the speaker to be claiming 'to be heading out the door' (6o) and that $\ddot{\eta} \kappa \omega$ (477) refers to a second singer who usurps the position claimed by the previous performer and that 'Simonides" remains in control' (61). There is indeed a rhetorical shift at line 475 from the address to Simonides to the speaker speaking in his own name ( $\dot{\xi} \gamma \dot{\omega})$ and directly addressing other members of the symposium, but the speaker remains the same throughout. 
he plays the fool (479-483). Such nepiosity has no place at our party! With $\alpha \lambda \lambda \dot{\alpha}$ $\sigma \dot{v}$ ('but you'), the speaker turns to a new addressee among the symposiasts who is to draw the lesson from the preceding exemplar of negative behavior: leave before getting plastered or stay, but stop drinking $(483-487)$. $\sigma \dot{\nu} \delta^{\prime}$ at line 487 again indicates a different guest and elicits a different rhetoric on the part of the speaker who here mocks and mimics the incessant empty babbling ( $\tau 0 \hat{\tau} \tau 0 \mu \dot{\alpha} \tau \alpha 10 v, 487$ ) of another member of the party, who just can't say 'No'. Finally, o $\tau \tau$ ¿ , who apparently lies near the previous symposiast, is his complete opposite: while drinking his fill, he manages nevertheless to say nothing vain or foolish ( $\mu \dot{\alpha} \tau \alpha \iota 0 \nu, 492$; cf. $\mu \dot{\alpha} \tau \alpha \iota 0 \nu$ line 487).

At this point, the speaker has presumably completed the tour of the guests. By my count, there are 11 in all, a fairly canonical number for a sympotic reunion. ${ }^{24}$ Praise and blame have been meted out, ending with an award ( $\dot{\alpha} v^{\prime}-$ « $\eta$ Tos) to the one who, like the speaker, can judiciously combine drinking and thoughtful talk (491-492). The individual members have now formed a unified

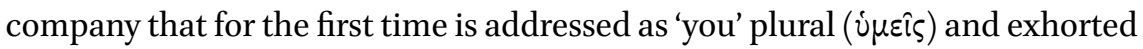
to continue appropriate drinking and speaking, and to avoid strife (493-495). The poem itself, as it circles the andron, has achieved the sense of community

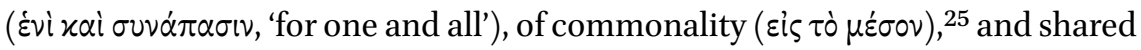

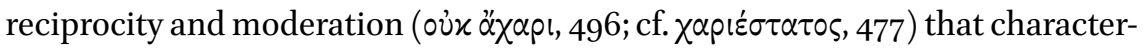
izes the symposium.

L.E. Rossi defined the symposium as a 'spettacolo a se stesso', emphasizing its self-sufficiency and its lack of need for external entertainment. ${ }^{26}$ But the phrase also indicates the high degree of self-consciousness that characterizes the Greek symposium. In a visual mise en abîme, the participants would drink from krateres and cups with sympotic scenes that mirrored themselves. ${ }^{27}$ These vessels frequently present images of the ideal symposium as well as of symposia gone wrong or out of hand; ${ }^{28}$ the Gorgon at the bottom of the kylix graphically

24 Note that the speaker ( $₹ \gamma \dot{\omega}, 475)$ introduces the second part of the poem and also is number seven and hence the central figure among the symposiasts. See Berquist (1990) and her tables on p. 40 and 42 . Tomlinson (1990) 95 notes that: 'By the end of the fifth century B.C. ... in public rather than private architecture, the eleven couch-room emerges as a standard'. Of course, we have little evidence for earlier private structures.

25 See Detienne (1965) for the significance of to meson as the focus of community.

26 Rossi (1983).

27 See, for example, Gericke (1970); and the tables in Schmitt-Pantel (1990) 27-30. Also Lissarrague (1990) 19-46 and passim.

28 Lissarrague (1990) 28. 
warns the drinker of the consequences of excess. Most notorious are those vases where the potters depicted themselves participating in drinking parties. ${ }^{29}$

Much archaic monody has a similarly meta-sympotic character. Each of the poems I have discussed constructs a spatio-visual image, a verbal icon, of the setting of the symposium, the andron. In the case of Alcaeus, the members of the hetairia are asked not to forget the armaments catalogued in a spatial sequence extending from the ceiling to the floor. Such an ordering itself facilitates recall and transforms the andron into a lieu de mémoire. This context inevitably calls to mind the famous anecdote that credits the poet Simonides with the invention of mnemonics within the framework of the symposium; ${ }^{30}$ the poet was able to recall the participants by re-envisioning their seating arrangements, no doubt by making a mental map of the andron. Through its ascending trajectory, the Xenophanes composition literally raises the level of discourse that the poet prescribes as appropriate to the chaste symposium he orchestrates; and the Theognidean elegiacs create a sympotic space via a tour of the andron, reenacting, no doubt, the age-old custom governing both drink and song, the traditional order epi dexia, from left to right. The symposiarchspeaker of the poem has asserted his authority, exhorting each guest in turn, transforming the motley crew into a unified company, and restoring the reciprocal harmony (charis) that is the hallmark of the symposium.

\section{Works Cited}

Berquist, B. (1990). 'Sympotic space: A functional aspect of Greek dining-rooms', in Murray (ed.) (1990): 37-65.

Bonanno, M.G. (1990). L'allusione necessaria. Ricerche intertestuali sulla poesia greca e latina. Rome: 125-146. (= 'Alcaeus fr. 140v'. Philologus 120 (1976): 1-11).

Bookides, N. (1990). 'Ritual dining in the sanctuary of Demeter and Kore in Corinth: Some questions', in Murray (ed.) (1990): 5-94.

Carrière, J. (1948). Théognis. Poèmes élégiaques. Paris.

Cirio, A.M. (1995). 'Alceo, Fr. 140v'. RccM 37: 179-186.

(2001). 'Nuovi dati sul culto degli eroi: una interpretazione di Alceo 140 v', in S. Ribichini, M. Rocchi, and P.Xella (eds), La questione delle influenze vicino-orientali sulla religione greca: prospettive della ricerca. Atti del colloquio internazionale, Roma 20-22 Maggio 1999. Rome: 299-305.

29 See Neer (2002) 87-134.

30 E.g. Cicero, De Oratore 2. 352-354; Quintilian Institutio oratoria 11.2.11-16. 
Colesanti, G. (1995). 'La disposizione delle armi in Alc. 140 V'. RFIC 123: 385-408.

Detienne, M. (1965). 'En Grèce archaïque: géométrie, politique et société. Annales 20: 425-441.

Faraone, C.A. (2008). The Stanzaic Architecture of Early Greek Elegy. Oxford.

Gerber, D. (1999). Greek Elegiac Poetry. Cambridge, MA.

Gericke, H. (1970). Gefäßdarstellungen aufgriechischen Vasen. Berlin.

Goldstein, M.S. (1978). 'The Setting of the Greek Ritual Meal in Greek Sanctuaries 6oo300 в.C.'. Ph.D. dissertation, Berkeley.

Hobden, F. (2013). The Symposion in Ancient Greek Society and Thought. Cambridge.

Kourayos, Y. (2005). 'Despotiko Mandra: A sanctuary dedicated to Apollo', in M. Yeroulanou and M. Stamatopoulou (eds), Architecture and Archaeology in the Cyclades: Papers in honour ofJ. J. Coulton. Oxford: 105-133.

Lesher, J.H. (1992). Xenophanes of Colophon. Fragments. Toronto.

Lissarrague, F. (1990). The Aesthetics of the Greek Banquet, transl. A. Szegedy-Maszak. Princeton (= Un Flot d'Images. Paris 1987).

Marcovich, M. (1978). 'Xenophanes on drinking parties and Olympic games'. ICs 3:1-26. Marzullo, B. (2009). Il "miraggio" di Alceo. Berlin.

Murray, O. (ed.) (1990) Sympotica: A Symposium on the Symposion. Oxford.

Neer, R. (2002). Style and Politics in Athenian Vase-Painting. Cambridge.

Page, D. (1955). Sappho and Alcaeus: An Introduction to the Study of Ancient Lesbian Poetry. Oxford.

Perrotta, G., Gentili, B., and Catenacci, C. (2007). Polinnia (third ed.). Florence.

Rösler, W. (1980). Dichter und Gruppe. Munich.

Rossi, L.E. (1983). 'Il simposio greco arcaico e classico come spettacolo a se stesso', in Spettacoli conviviali dall'antichità classica alle corti italiane del '4oo: Atti del VII ${ }^{\text {mo }}$ convegno di studi. Viterbo: 41-50.

Roux, G. (1973). 'Salles de banquets à Délos', in Études déliennes. BCH suppl. 1. Athens: 525-554.

Schmitt-Pantel, P. (1990). 'Sacrificial meal and symposion: Two models of civic institutions in the archaic city?', in Murray (ed.) (1990): 14-33.

_ (1992). La cité au banquet: Histoire des repas publics dans les cités qrecques. Rome.

Snodgrass, A.M. (1967). Arms and Armour of the Greeks. Ithaca, NY.

Spawforth, A. (2006). The Complete Greek Temples. London.

Tomlinson, R.A. (1990). 'The chronology of the Perachora hestiatorion and its significance', in Murray (ed.) (1990): 95-101.

Treu, M. (1952). Alkaios Lieder. Munich.

Will, E. (1976). 'Banquets et salles de banquet dans les cultes de la Grèce et de l'Empire romain', in P. Ducrey (ed.), Mélanges d'histoire anciennes et d'archéologie offerts à Paul Collart. Lausanne: $353-362$. 